\title{
Are there differences between the loading of an anaerobic capacity test and an agility test in basketball players?
}

\section{Há diferenças entre a carga de um teste de capacidade anaeróbica e um teste de agilidade em jogadores de basquete?}

\section{David Mancha-Triguero ${ }^{1}$ \\ (iD https://orcid.org/0000-0001-8080-7565 \\ Carlos David Gómez-Carmona' \\ (D) https://orcid.org/0000-0002-4084-8124 \\ José Martín Gamonales ${ }^{1}$ \\ (D) https://orcid.org/0000-0002-2444-1535 \\ Javier García-Rubio ${ }^{1}$ \\ (i) https://orcid.org/0000-0001-6426-0002 \\ Sergio J. Ibáñez \\ (D) https://orcid.org/0000-0001-6009-4086}

Abstract - The objective of this article was to know players' needs in the selected tests, to search for differences between categories and to know if there is any relationship between different tests. The sample consists of 2 teams ( $u-14, u-16, n=24)$, which were equipped with a WimuR inertial device. The selected tests were 2 agility tests and a lactic anaerobic capacity test. Neuromuscular and kinematic variables were selected. Descriptive analysis, inferential analysis and analysis of correlation among variables were carried out. Once players' needs are described, there are no significant differences among kinematic variables depending on the sample category. Nonetheless, there is relationship between kinematic and neuromuscular variables of the different tests. It is frequently claimed that capacity tests are those that cause more fatigue in athletes. For this reason, an analysis was carried out comparing a lactic anaerobic capacity test with an agility test in its two versions. The obtained results can facilitate the work and the evaluation time of a physical condition test since results of athletes in a capacity test could be known by performing tests of lesser requirement. In addition, this would avoid players from experiencing a situation of maximum effort and possible injury, also saving training time.

Key words: Basketball; Endurance; Physical fitness.

Resumo - O objetivo desse trabalho foi conhecer as demandas dos jogadores nos testes selecionados, buscar diferenças entre categorias e buscar conhecer se havia alguma diferença entre distintas provas. A amostra foi formada por duas equipes (sub-14, sub-16; $n=24$ ) que foram monitorados com dispositivo de inércia WimuR. Selecionaram-se dois testes de agilidade e um teste de capacidade anaeróbica lática, e testes para variáveis neuromusculares e cinemáticas. Empregou-se a análise descritiva e inferencial. Não houve diferenças significativas entre as variáveis cinemáticas, dependendo da categoria da amostra, porém houve relação entre as variáveis cinemáticas e neuromusculares. Afirma-se frequentemente que os testes de capacidade são os que causam maior fadiga no atleta. Por esse motivo, foi realizada uma análise na qual um teste de capacidade anaeróbica lática foi comparado com um teste de agilidade em suas duas versões. Os resultados obtidos podem facilitar o trabalho e o tempo de avaliação do teste de aptidão física, pois, ao realizar testes de menor exigência, os resultados do atleta podem ser conhecidos em um teste de capacidade, evitando que ele enfrente uma situação de esforço máximo, uma possível lesão e economia tempo de treinamento.

Palavras-chave: Aptidão física; Basquetebol; Resistência.
1 Facultad Ciencias del Deporte. Grupo de Optimización del Entrenamiento y Rendimiento Deportivo (GOERD). Universidad de Extremadura. Cáceres. España.

Received: 22 March 2019 Accepted: 15 August 2019

How to cite this article Mancha-Triguero D, Gómez-Carmona CD, Gamonales JM, García-Rubio J, Ibáñez SJ. Are there differences between the loading of an anaerobic capacity test and an agility test in basketball players? Rev Bras Cineantropom Desempenho Hum 2020, 22:e59837. DOI: http://dx.doi. org/10.1590/1980-0037.2020v22e59837

Copyright: This work is licensed under a Creative Commons Attribution 4.0 International License. 


\section{INTRODUCTION}

Basketball is a dynamic and intermittent invasion team sport, consisting of fast and short movements, where changes in speed, direction and jumps are an integral part of the game demands ${ }^{1}$. Moreover, at physiological level, basketball is characterized by requiring short-term maximum efforts, and with incomplete recovery between them ${ }^{2}$.

The analysis of all aspects that influence sport or competition gives the coach more information about individual and team performance.

Therefore, for correct training design, competition requirements should be taken as reference as they describe the actual conditions of the game. Adapting training to these demands cause adaptations in athletes that allow them to face competition successfully ${ }^{3}$. In invasive sports, sports performance is composed of different technical, tactical, psychological and physiological aspects ${ }^{4}$. Although the importance of each individual aspect is unknown, it has been shown that all aspects define the player's final performance and, consequently, the entire team. In this line, there is scientific evidence that identifies a correlation between physical capabilities and performance indicators, being the subject of recent studies, but there is controversy regarding the validity and reliability of data obtained due to the type of test used $^{5}$. General fitness tests are widely used to compare samples of different sports due to the existence of more reference values ${ }^{6}$. Sport-specific tests are also used, although to a lesser extent they appear in literature. These tests provide more accurate information about the athlete's state due to the similarity of the test to the sport or competition itself ${ }^{7}$. A large number of validated fitness tests, specific to a given sport, can be found in literature.

The analysis of the physical condition of athletes is one of the main aspects for training design, because during the season, the adaptations and needs of athletes are different, as well as the goals of their own tasks.

Therefore, monitoring the evolution of the athletes' physical condition will help the coaching staff to know the training level, detect possible irregularities and, if necessary, make training changes ${ }^{8}$.

Agility in basketball players can be a performance-limiting quality because the sport, due to its intrinsic nature, requires the athlete to make rapid movements in different directions on a court shared with different partners and opponents 9 .

Therefore, the player must be quick and agile to achieve possible advantages over the opponent player and reach the goal of advancing to the opponent $\operatorname{court}^{10}$. On the other hand, basketball is a dynamic sport that causes the athlete to perform maximum and submaximal efforts with incomplete recovery time ${ }^{11}$.

Therefore, the aims of this study are: (a) to characterize performance during the execution of a agility test and a lactic anaerobic endurance test specific in basketball, depending on the category; (b) to compare the requirements obtained in kinematic and neuromuscular variables between tests and among players of different teams; and (c) to identify the relationships among variables analyzed. 


\section{METHOD}

\section{Design}

This research is included in quasi-experimental empirical studies, which seek to examine differences between groups and relationships between tests, non-equivalent group design ${ }^{12}$ in order to characterize the performance of basketball players through physical fitness tests.

\section{Participants}

Twenty-four U-14 and U-16 players from two teams participating in the national championship and voluntary participated in this research (U-14: $n=$ $12, \mathrm{U}-16 ; n=12)$. Both coaching staff and players were informed in advance about the details of the investigation and its possible risks and benefits, and signed the informed consent form. In underage players, consent has been signed by their legal guardians. The study was developed based on the ethical provisions of the Declaration of Helsinki (2013) and was approved by the University Bioethics Committee (registration number 233/2019).

\section{Variables}

To evaluate athletes' performance, the following variables were analyzed, which are divided into two groups according to the type of requirement: neuromuscular variables and kinematic variables.

- Neuromuscular variables analyze the external load that the player receives in relation to the force of gravity: i) Player Load: is a vector magnitude derived from triaxial accelerometry data that quantifies the movement in high resolution. Accelerations and decelerations are used to construct a cumulative measure of the acceleration change rate. Accumulative measure (PL) and intensity measure (PL. $\left.\mathrm{min}^{-1}\right)$ are used and may indicate the stress rate at which the player is submitted for a certain period of time. As load unit, it has moderate-high degree of reliability and validity ${ }^{13}$. ii) Impacts: measured by the force that the musculoskeletal structures support in relation to gravity ( $\mathrm{G}$ force). They are classified into intensity levels ${ }^{6}$. Variables were relativized per minute for data equity.

- Kinematic variables analyze the external load that the player makes in relation to the execution time and its displacement: i) execution time of T-Test With / Without Ball: It is the amount of time (measured in seconds) that the player takes to complete the circuit. ii) Number of circuits performed (anaerobic test): This is the number of circuits performed by each player during the 5 periods during which the test lasts; each period is added in order to obtain the best result at the end of the test.

\section{Instruments and Materials}

To record time-movement and neuromuscular variables, each player was equipped with WIMU ${ }^{\circledR}$ inertial device, which was fixed with a harness anatomically adapted to each player. After registration, data were analyzed 
by the $\mathrm{S} P R O{ }^{\circledR}$ software (RealTrack Systems, Almería, Spain). In addition, Chrono jump photoelectric cells (Boscosystem, Barcelona, Spain) were used to record the time taken by players in each test.

For evaluation purposes, players performed the following physical tests:

- T-test without ball ${ }^{15}$ : player executes the T-shaped circuit in the shortest possible time. During the circuit, the player must move in front run, side run to both sides and back run.

- T-test with ball (modified ${ }^{15}$ ): Same as T-test without ball, but moves must be made while the player performs the steps action with the ball.

- SIG / ANA Anaerobic Test ${ }^{16}$ : The player should perform as many laps as possible on the circuit for one minute. The player repeats 5 times ( 5 minutes in total), with 1 minute recovery between periods ( 5 minutes in total). The test intersperses 5 minutes of maximum intensity with 5 minutes of recovery. The ability to repeat maximum activity with incomplete recoveries is evaluated. The test consists of displacement without ball, displacement with ball, throwing to the basket, back displacement, defensive movement and performing a rebound jump action.

\section{Procedure}

Each player performed the T-Test agility test (generally and specifically, with ball movement). Later, on the same day, they performed the SIG / ANA Anaerobic Test ${ }^{16}$. The order of tests was: i) T-Test without ball, ii) T-Test with ball, iii) SIG / ANA Anaerobic Test. The choice of order is due to an organization of duration time as it directly influences the type of energy used by the player to perform the proposed activity. Between the two tests, a 5-minute passive recovery was performed. Before the day of the evaluation of tests, athletes performed a familiarization session to prevent the lack of knowledge of the correct performance of tests from being a contaminating variable.

\section{Data analysis}

First, descriptive analysis of quantitative variables (Mean and Typical Deviation) was performed. Secondly, exploratory analysis was performed using the criterion assumption tests ${ }^{17}$, observing non-normal data distribution, so that nonparametric tests for the hypothesis contrast were performed. Finally, an analysis was performed to compare performance between categories using the Mann Whitney U-test and Spearman correlation analysis to identify the correlation among variables. The software used was SPSS 23.0 (SPSS Inc., Chicago IL, USA). Significance was set at $\mathrm{p}<0.05^{18}$.

\section{RESULTS}

Table 1 shows the descriptive results differentiated by categories. On the one hand, the U-14 team obtained lower scores on both Player Load per minute (PL / min) variables of the three tests and the Impacts per minute (Impacts / $\mathrm{min}$ ) variables compared to the U-16 team. On the other hand, the U-14 team 
traveled shorter distance in the anaerobic test compared to the U-16 team, and their values are higher in the execution time compared to the T-test. In relation to results obtained in the Mann Whitney U-test, it was shown that no variable obtained significant results except for time of the T- Test with ball.

Table 1. Descriptive and inferential results of variables analyzed in basketball teams

\begin{tabular}{lcccccc}
\hline & \multicolumn{2}{c}{ U-14 Team } & \multicolumn{2}{c}{ U-16 Team } & \multicolumn{2}{c}{$\begin{array}{c}\text { Mann Whitney } \\
\text { U-test }\end{array}$} \\
\hline & Mean & ST & Mean & ST & U & Sig. \\
\hline PL/min Anaerobic Test & 2.91 & 0.3 & 3 & 0.47 & 25.000 & .491 \\
PL/min T-Test CB & 3.25 & 0.6 & 3.62 & 0.67 & 16.000 & .101 \\
PL/min T-Test SB & 3.98 & 0.95 & 4.01 & 1.02 & 21.000 & .480 \\
Circuits Anaerobic Test & 120.44 & 10 & 122 & 11 & 29.000 & .791 \\
Time T-Test CB & 15.77 & 2.7 & 13.35 & 1.2 & 7.000 & $.010^{*}$ \\
Time T-Test SB & 13.87 & 1.9 & 12.72 & 0.87 & 16.000 & .101 \\
Impacts/min Anaerobic Test & 36.64 & 12 & 45.71 & 14 & 19.000 & .186 \\
Impacts/min T-Test CB & 19.86 & 3.6 & 26.98 & 4 & 19.000 & .638 \\
Impacts/min T-Test SB & 45.71 & 4.8 & 54.57 & 6.1 & 30.000 & .873 \\
\hline
\end{tabular}

${ }^{*} \mathrm{PL} / \mathrm{min}$ : Player Load/minute; T-Test CB: T-Test with ball; T-Test SB: T-Test without ball; Impacts/ min: Impacts/minute; Time measured in seconds.

Regarding the results of table 2, relationships among variables are observed. Variables PL / min and Impacts / min are significantly related (Impacts / min T-Test with Ball and Impacts / min T-Test without Ball; Impacts / min Anaerobic Test and Impacts / min T-Test with Ball; Impacts / min Anaerobic test and Impact / min T-Test without ball; PL / min T-Test with Ball and PL / min T-Test without ball; PL / min T-Test with ball with all variables except for number anaerobic circuits; PL / $\mathrm{min}$ T-Test without ball Impact / min Anaerobic Test and Impacts / min T-Test without ball; Impacts Anaerobic Test and Impacts T-Test without ball).

In addition, the time required to perform the T-Test (without ball) is related to the number of anaerobic test circuits in reverse, and the shorter

Table 2. Correlation results of analyzed variables

\begin{tabular}{|c|c|c|c|c|c|c|c|c|c|}
\hline & $\begin{array}{l}\text { PL/Min } \\
\text { Ana }\end{array}$ & $\begin{array}{c}\text { PL/Min } \\
\text { T-Test CB }\end{array}$ & $\begin{array}{l}\text { PL/Min T- } \\
\text { Test SB }\end{array}$ & $\begin{array}{c}\text { Circuit } \\
\text { Total Ana }\end{array}$ & $\begin{array}{c}\text { Time } \\
\text { T-Test CB }\end{array}$ & $\begin{array}{c}\text { Time } \\
\text { T-Test SB }\end{array}$ & $\begin{array}{l}\text { Impacts } \\
\text { Total Ana }\end{array}$ & $\begin{array}{l}\text { Impacts } \\
\text { T-Test CB }\end{array}$ & $\begin{array}{l}\text { Impacts } \\
\text { T-Test SB }\end{array}$ \\
\hline PL/Min Ana & & 0.137 & 0.121 & 0.527 & 0.837 & 0.897 & 0.008 & $0.044^{*}$ & 0.057 \\
\hline PL/Min T-Test CB & & & $0.007^{*}$ & 0.206 & $0.016^{*}$ & $0.008^{*}$ & $0.027^{\star}$ & $0.027^{*}$ & $0.013^{*}$ \\
\hline PL/Min T-Test SB & & & & 0.919 & 0.187 & 0.237 & 0.052 & 0.311 & $0.007^{*}$ \\
\hline Circuit Total Ana & & & & & 0.137 & $0.009^{*}$ & 0.816 & 0.734 & 0.391 \\
\hline Time T-Test CB & & & & & & $0.000^{*}$ & $0.008^{*}$ & 0.952 & 0.682 \\
\hline Time T-Test SB & & & & & & & 0.557 & 0.804 & 0.383 \\
\hline Impacts Total Ana & & & & & & & & $0.008^{*}$ & $0.003^{*}$ \\
\hline Impacts T-Test CB & & & & & & & & & $0.03^{*}$ \\
\hline Impacts T-Test SB & & & & & & & & & \\
\hline
\end{tabular}

${ }^{*} \mathrm{p}<.05 ;$ PL/min: Player Load/minute; T-Test CB: T-Test with ball; T-Test SB: T-Test without ball; Impacts/min: Impacts/minute. 
the time to perform the T-Test, the greater the number of circuits in the SIG / ANA Anaerobic Test.

\section{DISCUSSION}

The aims of this work were to know the physiological demands of an agility test and a lactic anaerobic capacity test, to compare the requirements obtained in the kinematic and neuromuscular variables between teams of different categories and to identify the relationships among analyzed variables, observing that there are no differences between teams, but there are relationships among variables.

It was observed that the under- 16 team obtained better results than the under-14 team. Regarding the analysis of variables analyzed according to the category, the results show significant differences only in time of the T- Test with ball. In this context, maturational development causes athletes differences between categories in terms of abilities such as agility, jumping strength or speed ${ }^{19}$. This may be due to the maturation process impacting the athlete, ensuring greater coordination of the ball movement technique.

Regarding the relational analysis of variables, there are specific and general test variables that are correlated. Thus, it is stated that one of the causes by which this correlation occurs may be the quality of players who have good technique. In situations of variable correlation, the coach should choose a specific test, because data quality and reliability will be higher ${ }^{5}$.

On the other hand, there is relationship among tests that evaluate different qualities or abilities, which is possible due to the fact that both tests not only evaluate the athlete's physical capacity, but also consider technicaltactical aspects of competition for greater specificity, since competition is the most powerful stimulus for athletes".

During the season, for different reasons, fitness tests are often scarce or extracted from indirect data in order not to require extra effort from the player or submit him to a period of great physical stress and generate a possible injury that would lead to temporary disability ${ }^{20}$.

Considering the selected tests, ability tests available in literature are described as maximum tests, while agility tests, due to their characteristics, generate temporary fatigue, and the player recovers in a short period of time ${ }^{21}$.

In this study, the results between lactic anaerobic capacity test and the two agility tests are similar among categories, since there are no significant differences among variables, except for the time of T-Test with ball. The data obtained in this study differ from those found in literature, in which it is mentioned that the maturational development of athletes affects the development of physical condition ${ }^{22}$. This may be due to different reasons, including the training methodology (we must justify why there are no differences between children and adolescents in tests when it should simply be due to maturational development).

Analyzing the results, there is possibility of saving the athlete's time and training efforts, with the main objective of minimizing the risk of 
fatigue and injury, because, although these tests evaluate different skills and qualities, the relative values per minute are similar and, there is correlation between neuromuscular and kinematic variables of the different tests.

A priori, lactic anaerobic capacity tests achieve maximum effort of the athlete, generating high fatigue and a possible acute performance deficit due to the duration and generation of lactic acid. In this paper, values of the lactic anaerobic capacity test and the two agility tests are similar among categories and there is correlation among variables. Contrary to results obtained, some authors have reported that ability tests obtain higher values in the athlete's demands than ability or agility tests ${ }^{21}$. This is possible due to the fact that agility tests are mainly tests that evaluate physical power ${ }^{22}$.

In this study, the results of both teams were combined in the analysis with the objective of, although the sample is heterogeneous, obtaining values to generalize results. The choice of the selected tests indicates that basketball is a hybrid sport with interval actions; therefore, these actions should be part of the training program and therefore should be analyzed ${ }^{23}$.

Since these abilities provide the player with better aerobic and anaerobic capacity, this is reflected in the athlete who has greater ability to perform the higher number of explosive and higher-intensity actions, which, in addition, are what make the difference between winning and losing teams ${ }^{8}$.

Taking into account the descriptive results obtained, it could be concluded that, in the T-test without ball, athletes perform greater number of rhythm changes that provide the game without the ball greater explosion and unpredictability, while in the T-test with ball, athletes make fewer changes, are less explosive and therefore perform smoother, continuous movements, which can be interpreted as predictable movements. These data may be related to the importance of introducing ball jumping in tests that indicate that not having a good command of the ball jumping technique limits the possibilities in the game. Higher-level players therefore have the ability to perform the same movements with the same intensity as when they perform them without moving the ball ${ }^{10}$.

\section{CONCLUSION}

It was concluded that, although the under- 16 team obtained better results in tests performed than the under-14 team, there are only significant differences in the time of T-test with ball, which may be due to the different aspects related to the technique of athletes who composed the sample. Finally, there are correlations among the same variables of different tests, among different variables of the same tests and among different variables of different tests; therefore, and with the main aim of minimizing training time, it could be inferred that, according to two tests with data equity, the choice should be the most specific, as the reliability and validity of data will be higher. This consideration can help save time in analyzing the physical condition of athletes and avoid submitting them to situations of maximum effort that may cause some type of injury or acute performance deficit. 


\section{COMPLIANCE WITH ETHICAL STANDARDS}

\section{Funding}

This work has been partially subsidized by the Aid to Research Groups (GR18170) from the Government of Extremadura (Department of Economy and Infrastructure); with the contribution of the European Union through the FEDER.

\section{Ethical approval}

Ethical approval was obtained from the local Human Research Ethics Committee-Universidad de Extremadura and the protocol (no. 233/2019) was written in accordance with standards set by the Declaration of Helsinki.

\section{Conflict of interest statement}

The authors have no conflict of interests to declare.

\section{Author Contributions}

Conceived and designed the experiments: DM-T, JG-R \& SJI. Performed the experiments: DM-T, CDG-C, \&JMG. Analyzed data: DM-T, CDGC, \& JMG. Contributed with reagents/materials/analysis tools: DM-T, CDG-C, JMG, JG-R, \& SJI. Wrote the paper: DM-T, CDG-C, JMG, JG-R, \& SJI.

\section{REFERENCES}

1. Zarić I, Dopsaj M, Marković M. Match performance in young female basketball players: relationship with laboratory and field tests. Int J Perf Anal Sport 2018;18(1):90-103.

2. Peyer KL, Pivarnik JM, Eisenmann JC., Vorkapich M. Physiological characteristics of National Collegiate Athletic Association Division I ice hockey players and their relation to game performance. J Strength Cond Res 2011;25(5):1183-1192.

3. Sarmento H, Marcelino R, Anguera MT, Campaniço J, Matos N, Leitão JC. Match analysis in football: a systematic review. J Sports Sci 2014;32(20):1831-1843.

4. Ziv G, Lidor R. Vertical jump in female and male basketball players-A review of observational and experimental studies. J Sci Med Sports 2009;13(3):332-9.

5. Jakovljevic ST, Karalejic MS, Pajic ZB, Macura MM, Erculj FF. Speed and agility of 12 and 14 years old elite male basketball players. J Strength Cond Res 2012;26(9):2453-2459.

6. Gomes JH, Rebello-Mendes R, Almeida MBD, Zanetti MC, Leite GDS, Ferreira Júnior AJ. Relationship between physical fitness and game-related statistics in elite professional basketball players: Regular season vs. playoffs. Motriz 2017;23(2):1-7.

7. Mancha D, Ibáñez, SJ, Reina M, Antúnez A. Comparative study about aerobic and anaerobic endurance for basketball players based on the training methodology. Sport TK 2017;6(1):183-192.

8. Ibáñez SJ, Sampaio J, Feu S, Lorenzo A, Gómez MA, Ortega E. Basketball game-related statistics that discriminate between teams' season-long success. Eu J Sport Sci 2008;8(6):369-372.

9. Green MR, Pivarnik JM, Carrier DP, Womack CJ. Relationship between physiological profiles and on-ice performance of a National Collegiate Athletic Association Division I hockey team. J Strength Cond Res 2006;20(1):43-46. 
10. Delextrat A, Cohen D. Physiological testing of basketball players: toward a standard evaluation of anaerobic fitness. J Strength Cond Res 2008;22(4):1066-1072.

11. McGill SM, Andersen JT, Horne AD. Predicting performance and injury resilience from movement quality and fitness scores in a basketball team over 2 years. J Strength Cond Res 2012;26(7):1131-1739.

12. Ato M, López JJ, Benavente A. Un sistema de clasificación de los diseños de investigación en psicología. Ana de Psi 2013;29(3):1038-1059.

13. Barreira P, Robinson MA, Drust B, Nedergaard N, Raja Azidin RMF, Vanrenterghem J. Mechanical Player Load ${ }^{\mathrm{TM}}$ using trunk-mounted accelerometry in football: Is it a reliable, task-and player-specific observation? J Sports Sci 2016,35(17);1-8.

14. Cunniffe B, Proctor W, Baker JS, Davies B. An evaluation of the physiological demands of elite rugby union using global positioning system tracking software. J Strength Cond Res 2009;23(4):1195-1203.

15. Bloomfield J, Polman R, O'donoghue P, McNaughton LARS. Effective speed and agility conditioning methodology for random intermittent dynamic type sports. J Strength Cond Res 2007;21(4):1093-1100.

16. Ibáñez SJ, Sáenz-López P, Gutiérrez A. Test anaeróbico SIG/ANA específico sobre el terreno, para jugadores de baloncesto (Abstract). Congreso Científico Olímpico 1995. Bioquímica, Fisiología del Ejercicio y Medicina del Deporte. Málaga: 1995, p. 209-216.

17. Cubo S. La investigación experimental. In Cubo S, Marín B, Ramos JL, organizadores. Métodos de investigación y análisis de datos en ciencias sociales y de la salud. Madrid: Ediciones Pirámide; 2011. p. 235- 328.

18. Pardo A, Ruiz, MA. SPSS 11. Guía para el análisis de datos. Madrid: Mc Graw Hill; 2002.

19. Krustrup P, Mohr M, Steensberg A, Bencke J, Kjaer M, Bangsbo J. Muscle and blood metabolites during a soccer game: implications for sprint performance. Med Sci Sports Exerc 2006;38(6):1165-1174.

20. Calleja-Gonzalez J, Leibar X, Terrados N. Análisis de la concentración de lactato en competición en jugadores internacionales junior de baloncesto. Arch Med Dep 2008; 25(123):11-18.

21. Walker S, Turner A. A one-day field test battery for the assessment of aerobic capacity, anaerobic capacity, speed, and agility of soccer players. Strength Cond 2009;31(6):52-60.

22. Salinero JJ, González-Millán C, Ruiz-Vicente D, Abián-Vicén J, García-Aparicio A, Rodríguez-Cabrero M, et al. Valoración de la condición física y técnica en futbolistas jóvenes. Int J Med Sci Phys Act Sport 2013;13(50):401-418.

23. Sekulic D, Pehar M, Krolo A, Spasic M, Uljevic O, Calleja-González J, et al. Evaluation of Basketball-Specific Agility: Applicability of Preplanned and Nonplanned Agility Performances for Differentiating Playing Positions and Playing Levels. J Strength Cond Res 2017;31(8):2278-2288.

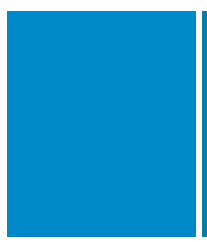

Corresponding author

David Mancha Triguero

Facultad de Ciencias del Deporte

Avenida de la Universidad s/n. Grupo de Optimización

del Entrenamiento y Rendimiento Deportivo (Grupo GOERD).

Cáceres (Cáceres), España. CP: 10003.

E-mail:dmanchat@alumnos.unex.es 